\title{
ANALYSIS CAUSALITY OF CAPITAL STRUCTURE AND PROFITABILITY OF BANKING SECTOR LISTED IN INDONESIAN STOCKS EXCHANGE: BUKU 1, BUKU 2, BUKU 3, AND BUKU 4 OF 2014-2018 PERIOD
}

\author{
Putri Darina*, Achsani Noer Azam, Bandono Bayu \\ School of Business, Bogor Agricultural University, Indonesia \\ ${ }^{\star}$ E-mail: darinaputris@gmail.com
}

\begin{abstract}
The company needs capital structure as a financial source. On another hand, profitability affects the capital structure component because if the company makes a profit then the profit will become retained earnings as additional equity. Thus, it needs to be seen the relationship between capital structure and profitability, whether it has a direct or two-way relationship. This needs to be examined considering the capital structure of banking companies in Indonesia which are listed on the Indonesian stock exchange on average by $84 \%$ or more companies use debt to carry out operational activities rather than using their equity. The higher the debt used, the higher the financial risk to be faced, thus the company must be able to manage its financial performance properly. This study aims to describe the relationship between capital structure and financial performance in Commercial Banks Business Activities 1, 2, 3 and 4 (BUKU 1, BUKU 2, BUKU 3 and BUKU 4). Capital structure variables used are TDTE and TDTA, profitability variables used are ROE and ROA, as well as financial performance variables consisting of SIZE, GROW, CAR, NIM, BOPO, NPL, LDR. The method used is granger causality. The result is in BUKU 1 capital structure (TDTE) can affect profitability (ROE), but not vice versa. And then, in BUKU 2 capital structure (TDTA) can affect profitability (ROE and ROA), but profitability does not affect capital structure. On another side, in BUKU 3 capital structure and profitability do not affect each other. But, in BUKU 4 Bank profitability (ROA) can affect the capital structure (TDTE and TDTA), but not vice versa.
\end{abstract}

\section{KEY WORDS}

Capital structure, profitability, Indonesia banking performance, panel data, Granger causality.

Banks as intermediary institutions have the main task of collecting funds from the public in the form of Third Party Funds (DPK) and channeling it back to the people who need it in the form of credit. Thus, the capital structure becomes a crucial factor that must be determined by the company's management to determine the level of profitability of the company, where the optimal capital structure can reduce the cost of capital so that it will increase the profitability of the company. Capital structure decisions play an important role in a company's performance (Siddik et al 2017). Companies need to pay attention to the optimal capital structure and dynamically the capital structure will be adjusted to investment choices (Bradley et al 1984; Titman and Tsyplakov 2007). The choice of composition of the capital structure depends on the category of the company and its industry (Kim 2005; Khalid 2011). Research conducted by Gornall and Strebulaev (2018) on the capital structure of banks and non-bank companies in the US found that there were differences in capital structure between banks and non-bank companies, where the benchmark debt rate was $85 \%$ and the benchmark debt level of non-bank companies was 30\% Gornall and Strebulaev (2018) continue that this difference occurs because banks have higher debt to reduce the decline in asset values and reduce credit risk due to lending to non-bank companies, while non-bank companies have lower debt to reduce the risk of the company's inability to repay the debt. In Indonesia, the average capital structure of banks listed on the Indonesia Stock Exchange is $84 \%$. In addition to capital structure, profitability also has an important role in determining the level of success of a company. The better the financial performance of a company, the higher the level of profitability of the company. On the other hand, profits 
obtained by companies can be used as additional capital in the form of retained earnings and will have an impact on the company's capital structure. Thus, research is conducted to determine the relationship between capital structure and profitability.

The Financial Services Authority (OJK) divides bank groups based on the core capital owned by each of these banks or more commonly known as a grouping based on Commercial Banks Business Activities (BUKU). There are 4 (four) BUKU groups, namely BUKU 1 with a core capital of less than 1 billion, BUKU 2 with a core capital of 1 billion to 5 billion, BUKU 3 with a core capital of less than 5 billion to 30 billion, and BUKU 4 with a core capital of more than 30 billion. The higher the BUKU, the greater the opportunity for the Bank to diversify its business activities.

In this study, the objects of study are 34 banks listed on the Indonesia Stock Exchange in the period 2014 to 2018 were grouped based on BUKU 1, BUKU 2, BUKU 3 and BUKU 4. The test variable is the capital structure measured based on Total Debt to Total Assets (TDTA) and Total Debt to Total Equity (TDTE), profitability measured by Return on Equity (ROE) and Return on Assets (ROA), and other internal banking variables measured by company size (SIZE), company growth (GROW), Capital Adequacy Ratio (CAR), Net Interest Margin (NIM), Operating Costs Operating Income (BOPO), Non Performing Loans (NPL), and Loans to Deposits Ratio (LDR).

\section{LITERATUR REVIEW}

The bank is a financial institution that functions as a financial intermediary between parties that have excess funds (surplus spending units) with those who need funds (deficit spending units) in the form of credit and provide services in the payment traffic and circulation of money. According to Kasmir (2013) as a financial intermediary, bank activities are as follows: (1) raising funds from the public in the form of deposits, in general, the types of deposits in banks are demand deposits, demand deposits, savings deposits, and savings deposits time deposits; (2) channeling funds to the public in the form of credit, in general, based on the purpose of the use of credit provided by banks can be in the form of working capital loans, investment loans, and consumer loans; (3) providing other bank services, such as money transfers (transfers), safekeeping using safe deposit boxes, collection of securities originating from out of town and abroad (collections), and issuance of letters of credit (L/C), bank guarantees, banknotes, travelers checks and other types of banking services.

Capital structure can be measured using TDTE. TDTE value reflects the percentage of the total debt compared to the total equity of the company. The higher TDTE value, can reflect the higher the debt held by the company. TDTE can be formulated as follows:

$$
\text { TDTE }=\frac{\text { total debt }}{\text { total equity }} \times 100 \%
$$

The capital structure can also be measured using TDTA. The value of TDTA can reflect how much assets are financed by debt. The higher the TDTA value, the more company assets are financed by debt. TDTA can be formulated as follows:

$$
T D T A=\frac{\text { total debt }}{\text { total assets }} \times 100 \%
$$

ROE is a return on equity obtained on investment or operational activities in the company in a certain period. The amount of ROE influenced by profits obtained by the company. The higher the profit obtained, the higher the increase in ROE. ROE can be formulated as follows:

$$
R O E=\frac{\text { total equity }}{\text { total assets }} \times 100 \%
$$


ROA is the result of total asset returns that can show how much net income can be obtained from the use of total assets owned by the company, thus ROA can be a measure of management effectiveness in generating profits with assets available to the company (Sundjaja and Barlian 2001; Husnan and Pudjiastuti 2003; Horne et al. 2005). ROA measurement is an indicator of the effectiveness of the use of assets owned by the company and can help company management to evaluate the return on investment in assets so that it can be optimized in the next period. ROA can be formulated as follows:

$$
R O A=\frac{\text { profit before tax }}{\text { total assets }} \times 100 \%
$$

Large companies generally diversify their businesses so that bankruptcy is less likely to occur so that large companies have the ease to increase corporate debt (Titman and Wessel (1988); Mazur (2007); Chen Yang et al. 2010). Ozkan (2001) states that small companies will have a low debt ratio because small companies have the possibility of bankruptcy big enough to be liquidated when in a state of financial distress. SIZE can be formulated as follows:

$$
S I Z E=\mathrm{LN} \frac{\text { total sales }_{\mathrm{t}}}{\text { total sales }_{\mathrm{t}-1}}
$$

The company's growth can be seen from the assets it has. Chen Yang et. al. (2010) states that companies with high growth rates tend to have greater agency costs, so as to minimize the number of agency costs a company is expected to have a low level of debt. GROW can be formulated as follows:

$$
\text { GROW }=\frac{\left(\text { total }_{\text {assets }}-\text { total sales }_{\mathrm{t}-1}\right)}{\text { total }_{\text {sales }} \text { (t-1 }} \times 100 \%
$$

CAR is a capital adequacy ratio that shows the ability of banks to provide funds used to overcome the possibility of loss risk. This ratio is important because by keeping CAR at a safe limit (at least $8 \%$ ), it also means protecting customers and maintaining overall financial system stability. CAR can be formulated as follows:

$$
C A R=\frac{\text { bank capital }}{\text { Risk Weighted Assets }} \times 100 \%
$$

NIM is a ratio used to analyze large net interest income compared to a company's productive assets. The greater the value of the NIM Realizing the ability of banks to increase income derived from increased income the better. NIM can be formulated as follows:

$$
N I M=\frac{\text { net interest income }}{\text { average productive assets }}
$$

BOPO is a ratio that describes the efficiency of banks in carrying out their activities. Operational expenditure is interest expense given to customers while operating income is interest earned from customers. The smaller the value of BOPO means more efficient banking in operating. BOPO can be formulated as follows:

$$
B O P O=\frac{\text { total operating cost }}{\text { total operating income }} \times 100 \%
$$

NPL is a credit quality ratio that shows the ability of banks to maintain credit quality given to debtors. The regulator determines that the bank NPL must be below $5 \%$, thus the smaller the NPL, the better. NPL can be formulated as follows: 


$$
N P L=\frac{\text { non performing loan }}{\text { total loan }} \times 100 \%
$$

LDR is a ratio that measures the ability of banks to meet short-term liabilities (can be called liquidity) by dividing total loans to total Third Party Funds (DPK). Banking liquidity needs to be managed to meet the needs when customers take their funds and distribute loans (credit) to borrowers (debtors). If the LDR value is too high, it means that the bank does not have sufficient liquidity to cover its obligations to customers (DPK). Conversely, if the LDR value is too low, it means that banks have sufficient liquidity but their income may be lower because as is well known, the banking world earns income through loans. LDR can be formulated as follows:

$$
L D R=\frac{\text { the amount of credit given }}{\text { the third }- \text { party funds }} \times 100 \%
$$

\section{METHODS OF RESEARCH}

The type of the data used in this study was panel data. The type of data used in this study is secondary data. The data source is derived from the audited financial statements of each Conventional Bank as of December 31 during the period 2014-2018 through the official website of each Bank. Other data used in this study were taken from several sites, including the official IDX website, the official website of the Financial Services Authority (OJK), and the official website of Bank Indonesia (BI).

The test variable is the capital structure measured based on Total Debt to Total Assets (TDTA) and Total Debt to Total Equity (TDTE), profitability measured by Return on Equity (ROE) and Return on Assets (ROA), and other internal banking variables measured by company size (SIZE), company growth (GROW), Capital Adequacy Ratio (CAR), Net Interest Margin (NIM), Operating Costs Operating Income (BOPO), Non Performing Loans (NPL), and Loans to Deposits Ratio (LDR).

Granger causality is used to determine whether there is a simultaneous relationship between two variables. The results of Granger causality can describe whether a variable has a direct relationship or a two-way relationship seen from the influence of the past on the present conditions. Before conducting the Granger Causality, an optimal lag determination is performed. The number of lags is used to see the effect of the Granger Causality in what period is ahead.

\section{RESULTS OF STUDY}

Optimal lag is determined by the value of the Akaike Information Criterion (AIC). The optimal lag chosen is the lag with the smallest AIC value. Table 1 shows the optimal lag test results on BOOK 1 . The test results show that the optimal lag that can be used is lag 2 , which means that the current year's data is influenced by the previous 2 years' data.

Table 1 - Results of Optimal Lag Testing on BUKU 1

\begin{tabular}{ccc}
\hline Lag & LogL & AIC \\
\hline 0 & $-206,9590$ & 28,1279 \\
\hline 1 & $-188,1045$ & 27,7473 \\
\hline 2 & $-156,4723$ & $25,6630^{*}$ \\
\hline
\end{tabular}

Figure 1 shows the causality relationship at BUKU Bank 1. In BUKU 1 Bank capital structure (TDTE) can affect profitability (ROE), but not vice versa. The other internal variables that have a two-way influence on capital structure (TDTE and TDTA) are SIZE and GROW, while other internal variables that have a two-way effect on profitability (ROE and $\mathrm{ROA})$ are BOPO. 


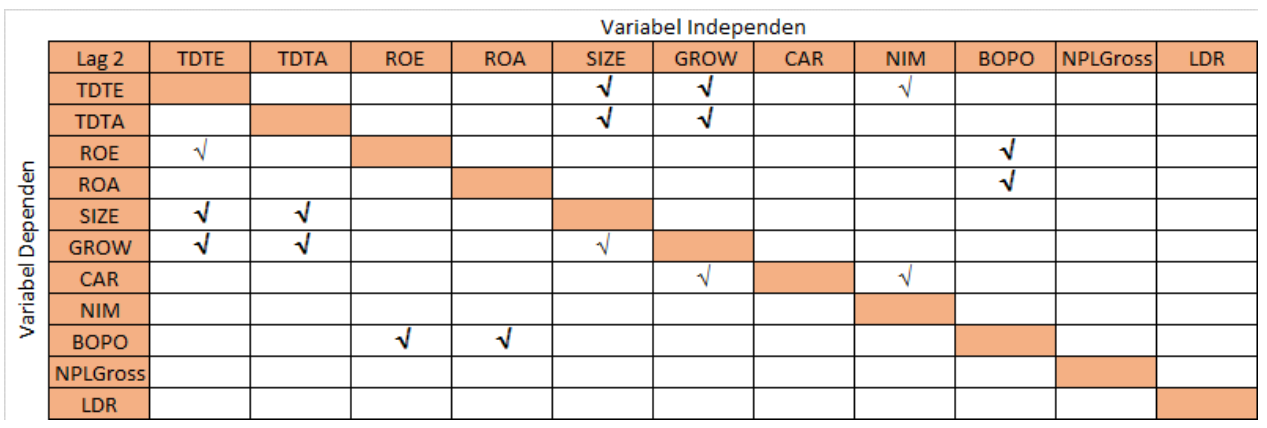

Figure 1 - Result of Granger Causality on BUKU 1

Table 2 shows the optimum lag test results at BUKU Bank 2. The test results show that the optimal lag that can be used is lag 1, which means the current year's data is influenced by the previous year's data.

Table 2 - Results of Optimal Lag Testing on BUKU 2

\begin{tabular}{ccc}
\hline Lag & LogL & AIC \\
\hline 0 & $-367,0955$ & 26,5068 \\
\hline 1 & $-263,3157$ & $20,2368^{*}$ \\
\hline 2 & $-252,7446$ & 20,6246 \\
\hline 3 & $-233,0267$ & 20,3591 \\
\hline
\end{tabular}

${ }^{*}$ indicates lag order selected by the criterion

Figure 2 shows the causality relationship at BUKU Bank 2. In BUKU Bank 2 capital structure (TDTA) can affect profitability (ROE and ROA), but profitability does not affect capital structure. Other variables that can be influenced by capital structure (TDTA) in the same direction are BOPO and LDR, while other variables that can be influenced by profitability (ROE) are GROW.

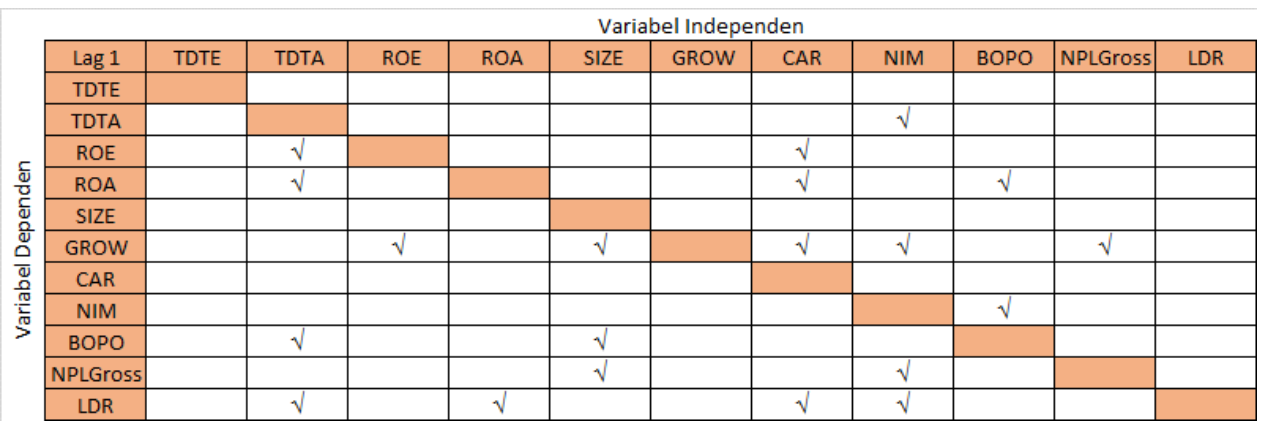

Figure 2 - Result of Granger Causality on BUKU 2

Table 3 shows the optimum lag test results at BUKU Bank 3. The test results show the optimal lag that can be used is lag 3 because it has the smallest AIC value. Thus using lag 3 in the model will show that the current year's data is influenced by the previous 3 years data.

Table 3 - Results of Optimal Lag Testing on BUKU 3

\begin{tabular}{ccc}
\hline Lag & LogL & AIC \\
\hline 0 & $-203,0303$ & 23,0034 \\
\hline 1 & $-165,0873$ & 20,5653 \\
\hline 2 & $-146,7360$ & 20,3040 \\
\hline 3 & $-126,2035$ & $19,8004^{*}$ \\
\hline${ }^{*}$ indicates lag order selected by the criterion & \\
\hline
\end{tabular}

Figure 3 shows the results of the causality test at BUKU Bank 3. In BUKU Bank 3 capital structure and profitability do not affect each other. Other internal variables that are 
affected by profitability (ROA) in the same direction are NIM, while other internal variables that influence each other are SIZE and NPL.

\begin{tabular}{|c|c|c|c|c|c|c|c|c|c|c|c|}
\hline & \multicolumn{11}{|c|}{ Variabel Independen } \\
\hline Lag 3 & TDTE & TDTA & ROE & ROA & SIZE & GROW & CAR & NIM & BOPO & NPLGross & LDR \\
\hline TDTE & & & & & & & & & & & \\
\hline TDTA & & & & & & & & & & & \\
\hline ROE & & & & & $\sqrt{ }$ & & & & & & \\
\hline ROA & & & & & $\sqrt{ }$ & & & & & & \\
\hline SIZE & & & & & & & & & & $\sqrt{ }$ & \\
\hline GROW & & & & & & & & & & & \\
\hline CAR & & & & & & $\sqrt{ }$ & & & & & \\
\hline NIM & & & & $\sqrt{ }$ & & & & & $\sqrt{ }$ & & \\
\hline BOPO & & & & & $\sqrt{ }$ & & & & & & \\
\hline NPLGross & & & & & $\sqrt{ }$ & & & & & & \\
\hline LDK & & & & & & & & & & & \\
\hline
\end{tabular}

Figure 3 - Result of Granger Causality on BUKU 3

Table 4 shows the optimum lag test results at BUKU Bank 4. The test results show the optimal lag that can be used is lag 1 , which means the current year's data is influenced by the previous year's data.

Table 4 - Results of Optimal Lag Testing on BUKU 4

\begin{tabular}{ccc}
\hline Lag & LogL & AIC \\
\hline 0 & $-132,7155$ & 15,1906 \\
\hline 1 & $-91,22625$ & $12,3585^{\star}$ \\
\hline 2 & $-76,35978$ & 12,4844 \\
\hline${ }^{*}$ indicates lag order selected by the criterion & \\
\hline
\end{tabular}

Figure 4 shows the results of the causality test at Bank BUKU 4. At Bank BUKU 4 profitability (ROA) can affect the capital structure (TDTE and TDTA), but not vice versa. Also, it was found that the capital structure measured by TDTA can affect the capital structure measured by TDTE. Capital structure (TDTE and TDTA) can affect GROW in the same direction, while profitability (ROA) can affect CAR in the same direction. Other internal variables that have a two-way relationship with profitability are GROW and NIM to ROE and SIZE to ROA.

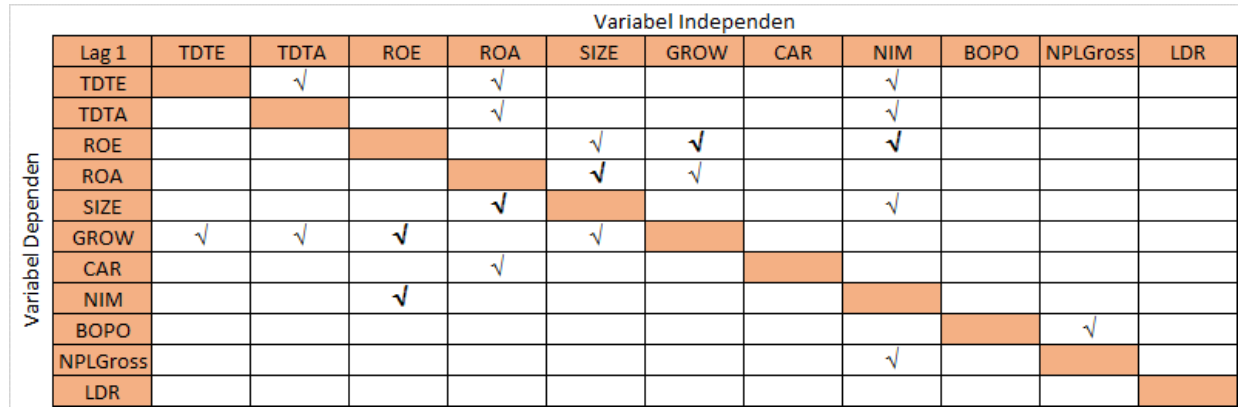

Figure 4 - Result of Granger Causality on BUKU 4

\section{CONCLUSION}

The result is in BUKU 1 capital structure (TDTE) can affect profitability (ROE), but not vice versa. And then, in BUKU 2 capital structure (TDTA) can affect profitability (ROE and ROA), but profitability does not affect capital structure. On another side, in BUKU 3 capital structure and profitability do not affect each other. But, in BUKU 4 Bank profitability (ROA) can affect the capital structure (TDTE and TDTA), but not vice versa. From the results of the study, it can be seen that the capital structure in BUKU 1 and BUKU 2 can affect profitability, so management must determine the optimal capital structure by considering the level of profit targeted by the company. On the other hand, in BUKU 4 profitability can influence the 
determination of capital structure. In large banks, the sales capacity and the possibility to get profits are also getting bigger, so that as a source of financing these large banks will prefer to use internal funds from company profits rather than debt.

\section{REFERENCES}

1. Bradley M, Jarrel GA, Kim EH. 1984. On the existence of an optimal capital structure: theory and evidence. The Journal of Finance. 39 (3):857-878.

2. Chen Y, Chau, Few L, Cheng, Xiang G, Yan, Wen L, Yen. 2010. Codetermination of capital structure and stock returns: A Lisrel approach, An empirical test of Taiwan stock markets. The Quarterly Review of Economics and Finance. 50:222-233

3. Gornall W, Strebulaev IA. 2018. Financial as a supply chain: the capital structure of banks and borrowers. Journal of Financial Economics. 129(2018): 510-530.

4. Horne V, James C, Machowicz JM JR. 2005. Fundamental of Financiall Management/Prinsip-prinsip Manajemen Keuangan. Ed ke-12. Jakarta (ID): Salemba Empat.

5. Husnan S, Pudjiastuti E. 2004. Dasar-dasar Manajemen Keuangan. Yogyakarta (ID): UPP AMP YKPN.

6. Kasmir. 2013. Bank and Lembaga Keuangan Lainnya. Ed rev 2008. Jakarta (ID): Raja Grafindo Press.

7. Kim Y. 2005. FDI and determinants of capital structure [disertasi]. Columbia (US): University of Missouri.

8. Khalid S. 2011. Financial reforms and dynamics of capital structure choice: a case of publically listed firms of Pakistan. Journal of Management Reasearch. 3(1):1-16.

9. Mazur K. 2007. Determinants of capital structure choice: Evidence from polish companies. International Atlantic Economic Society. 13:495-514

10. Ozkan A. 2001. Determinants of capital structure and adjustment to long run target: Evidence from UK company panel data. Journal of Business Finance and Accounting. 28(1) \& (2): 175-198.

11. Siddik MNA, Kabiraj S, Joghee S. 2017. Impacts of Capital Structure on Performance of Banks in a Developing Economy: Evidence from Bangladesh. International Journal of Financial Studies. 5(13):1-18.

12. Sudjaja, Barlian. 2001. Manajemen Keuangan. Jakarta (ID): Prenhallindo.

13. Titman S, Tsyplakov S.2007. A dinamic model of optimal capital structure. Review of Finance. 11 (3): 401-451.

14. Titman S, Wessels R. 1988. The determinans of capital structure choice. Jurnal of Finance. 18:1-19. 